\title{
The effect of supplementing a symbiotic, organic acids, or $\beta$-glucanase to barley-based diets on the performance of broiler chickens
}

\author{
D. Józefiak ${ }^{1,2}$ and A. Rutkowski \\ The August Cieszkowski Agricultural University of Poznań, \\ Department of Animal Nutrition and Feed Management \\ Wotyńska 33, 60-637 Poznań, Poland
}

\section{ABSTRACT}

A total of 384 male broiler chickens were divided into four groups, 12 replicates each with 8 birds per replicate. Four barley-based diets were prepared. The control diet (C) was unsupplemented, $\operatorname{diet}$ A was supplemented with flavomycin $(10 \mathrm{mg} / \mathrm{kg})$, diet OS was supplemented with organic acids $(3 \mathrm{~g} / \mathrm{kg})$ and a symbiotic composed of a probiotic and lactose $(1: 2, \mathrm{w} / \mathrm{w})$, diet $\mathrm{E}$ was supplemented with $\beta$-glucanase ( $1 \mathrm{~g} / \mathrm{kg})$. Diets were fed from 1 to 35 days of age. In the OS group the body weight gain (BWG) was highest $(\mathrm{P}<0.05)$, while feed conversion ratio $(\mathrm{FCR})$ was similar as in group $\mathrm{E}$, but better $(\mathrm{P}<0.05)$ than in groups $\mathrm{A}$ and $\mathrm{C}$. The viscosity of ileal digesta was 1.55 in group $\mathrm{E}$, while in the remaining groups it averaged $2.37 \mathrm{mPas} \mathrm{s}(\mathrm{P}<0.05)$. The $\mathrm{pH}$ of caecal digesta was lowest in group OS (5.88), followed by $\mathrm{E}(6.06)$, while in groups $\mathrm{A}$ and $\mathrm{C}$ groups it averaged $6.33(\mathrm{P}<0.05)$, which points to increased production of short-chain fatty acids. It seems that a combination of organic acids and a symbiotic can replace antibiotic growth promoters in broiler diets.

KEY WORDS: broiler chicken, feed antibiotic, organic acids, symbiotic, $\beta$-glucanase

\section{INTRODUCTION}

In recent years interest has been growing in feed additives that can be alternatives for antibiotic growth promoters (AGP). This includes mixtures of organic acids, prebiotics, probiotics, symbiotics and feed enzymes. The mode of their action differs, but all are considered to be bacteriostatic agents. The objective of the experiment was to study the influence of organic acids in combinations with symbiotics and $\beta$-glucanase in barley-based diets on the performance of broiler chickens as well as the ileal viscosity and $\mathrm{pH}$ of digesta.

\footnotetext{
${ }^{1}$ The author is a recipient of support from The Foundation for Polish Science

${ }^{2}$ Corresponding author: e-mail: damjo@owl.au.poznan.pl
} 


\section{MATERIAL AND METHODS}

A total of 384 Cobb 500 male broiler chickens was allocated into four dietary treatments, each with 12 replicates, 8 birds per replicate, housed in floor pens. Four barley-based diets were prepared. The control diet (C) was unsupplemented, diet A was supplemented with flavomycin $(10 \mathrm{mg} / \mathrm{kg})$, diet $\mathrm{E}$ was supplemented with $1 \mathrm{~g} / \mathrm{kg}$ of feed enzyme (Avizyme ${ }^{\circledR} 1100$, Danisco, UK), diet OS was supplemented with $3 \mathrm{~g} / \mathrm{kg}$ organic acid mixture (Salacid Balance Dry) and $3 \mathrm{~g} / \mathrm{kg}$ of a symbiotic [a probiotic preparation (Enterococcus faecium ATCC 53519 and Enterococcus faecium ATCC 55593 ) and purified lactose (1:2, w/w)]. Feed intake and body weight were measured at weekly intervals, and feed conversion ratio (FCR) and body weight gain (BWG) were calculated. At the end of the experiment ten birds from each group were slaughtered, digesta from different parts of the gastrointestinal tract were collected and the $\mathrm{pH}$ was measured with a combined glass/reference electrode. The ileal content was centrifuged for $8 \mathrm{~min}$ at $8000 \mathrm{rpm}$ and the viscosity of the supernatant measured with a Brookfield DV-II+ cone/plate viscometer (Brookfield Engineering Laboratories, Stoughton, USA). The results were analysed statistically using the software package SAS (1996), SAS ${ }^{\circ} / \mathrm{STAT}$.

\section{RESULTS AND DISCUSSION}

The highest final BWG was in the OS followed by C, E and A groups $(\mathrm{P}<0.05)$. Birds from groups $\mathrm{OS}$ and $\mathrm{E}$ receiving additives that were potentially alternatives for AGP, had better FCR (Table 1). One of the main functions of exogenous enzymes against the antinutritive effects of soluble NSP is reduction of viscosity in intestinal digesta (Bergh et al., 1999; Silva and Smithard, 2002). In our study, the addition of $\beta$-glucanase to the diet significantly reduced intestinal viscosity in comparison with the remaining groups, but it was not reflected in better BWG (Table 1). On the other hand, there was no mortality in group E, and FCR was better in comparison with groups $\mathrm{A}$ and $\mathrm{C}(\mathrm{P}<0.05)$. Also in our earlier experiments, exogenous enzymes only tended to improve BWG but significantly reduced FCR (Józefiak et al., 2004). The lower BWG in group E may be partially explained by reduction in the weight of gastrointestinal tract and adipose tissue. These factors are suggested to be other advantages of dietary enzyme effects (Bergh et al., 1999). In the study, birds from group OS receiving a diet supplemented with a symbiotic preparation and mixture of organic acids had the highest BWG. This may suggest that in growing broilers with fast intestinal passage, the probiotic strains of bacteria need additional nourishment (i.e. lactose), which may enhance their activity in the gastrointestinal tract. In the crop, the highest $\mathrm{pH}$ was found in the flavomycin-supplemented group, 
while the lowest, in the $\beta$-glucanase-supplemented one (Table 1). The caeca are the main fermentative chambers in the broiler chicken gastrointestinal tract where undigested carbohydrates can be fermented by the chickens' resident

Table 1. Effect of additives on performance, ileal viscosity ( $\mathrm{mPas} \mathrm{s}$ ) and digesta $\mathrm{pH}$ in broilers

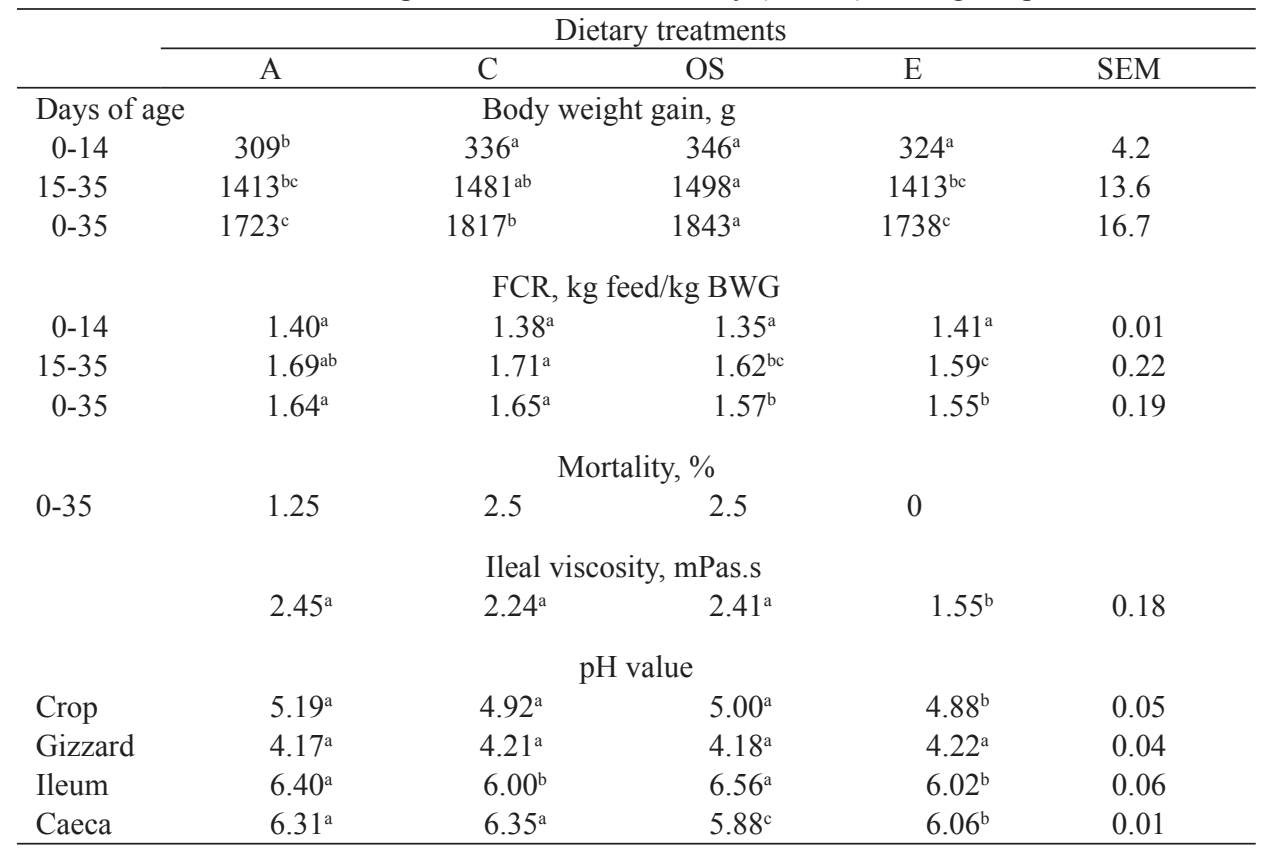

${ }^{a, b}$ means in rows with different letters are significantly different at $\mathrm{P} \leq 0.05$

microflora to lactic acid, short-chain fatty acids (SCFA) and gasses (Józefiak et al., 2004). In the present study, the lowest $\mathrm{pH}$ in caecal content was measured in group OS followed by groups $\mathrm{E}, \mathrm{A}$ and $\mathrm{C}$. This could be explained by the presence of lactose in the diet, which enhances the fermentation and production of SCFA and lowers the $\mathrm{pH}$ of caecal digesta. The $\mathrm{pH}$ reduction is one of the reasons why organic acids are used as antibacterial feed additives (Ricke, 2003). Surprisingly, in group OS, where a mixture of organic acids was included in the diet, the $\mathrm{pH}$ in the ileum was significantly higher than in groups $\mathrm{C}$ and $\mathrm{E}$.

\section{CONCLUSIONS}

It can be concluded that supplementation with a combination of organic acids and symbiotic might be an alternative to antibiotic growth promoters in broiler chicken diets. 


\section{REFERENCES}

Bergh M.O., Razdan A., Åman P., 1999. Nutritional influence of broiler chicken diets based on covered normal, waxy and high amylose barleys with or without enzyme supplementation. Anim. Feed Sci. Tech. 78, 215-226

Engberg R.M., Hedemann M.S., Jensen B.B., 2002. The influence of grinding and pelleting of feed on the microbial composition and activity in the digestive tract of broiler chickens. Brit. Poultry Sci. 43, 569-579

Engberg R.M., Hedemann M.S., Leser T.D., Jensen B.B., 2000. Effect of zinc bacitracin and salinomycin on intestinal microflora and performance of broilers. Poultry Sci. 79, 1311-1319

Józefiak D., Rutkowski A., Frątczak M., Boros D., 2004. The effect of dietary fibre fractions from different cereals and microbial enzymes supplementation on performance ileal viscosity and short-chain fatty acids concentration in caeca of broiler chickens. J. Anim. Feed Sci. 13, $487-$ 496

Józefiak D., Rutkowski A., Martin S.A., 2004. Carbohydrate fermentation in the avian ceca. A review. Anim. Feed. Sci. Tech. 113, 1-15

Ricke S.C., 2003. Perspectives on the use of organic acids and short chain fatty acids as antimicrobials. Poultry Sci. 82, 632-699

SAS, 1996. SAS ${ }^{8} /$ STAT User`s Guide: Statistics Cary, NC, SAS Institute Inc.

Silva S.S.P., Smithard R.R., 2002. Effect of enzyme supplementation of a rye-based diet on xylanase activity in the small intestine of broilers, on intestinal crypt proliferation and nutrient digestibility and growth performance of the birds. Brit. Poultry Sci. 43, 274-282

\section{STRESZCZENIE}

\section{Wpływ dodatku symbiotyku i kwasów organicznych lub $\beta$-glukanazy do diety z jęczmieniem na wyniki odchowu, lepkość treści jelita cienkiego i pH treści u kurcząt brojlerów}

Trzysta osiemdziesiąt cztery kogutki brojlery podzielono na 4 grupy, po 12 powtórzeń w każdej, i po 8 ptaków w powtórzeniu. Przygotowano 4 diety jęczmienne: dieta $\mathrm{C}$ była nieuzupełniona, do diety A dodano antybiotyk paszowy flawomycynę $(10 \mathrm{mg} / \mathrm{kg})$, do diety OS dodano mieszaninę kwasów organicznych $(3 \mathrm{~g} / \mathrm{kg})$ i symbiotyku $(3 \mathrm{~g} / \mathrm{kg})$, zawierającego w swoim składzie probiotyk i laktozę $(1: 2 \mathrm{w} / \mathrm{w})$, do diety E dodano $\beta$-glukanazę $(1 \mathrm{~g} / \mathrm{kg})$. Diety skarmiano od 1 do 35 dnia życia. $\mathrm{W}$ grupie OS przyrosty były najwyższe $(\mathrm{P}<0,05)$, podczas gdy wykorzystanie paszy podobne jak w grupie E, lecz lepsze niż w grupach A i C. Lepkość treści jelita cienkiego wynosiła w grupie E 1,55, w pozostałych grupach średnio $2,37 \mathrm{mPas} . \mathrm{s}(\mathrm{P}<0,05)$. W treści jelit ślepych $\mathrm{pH}$ było najniższe $\mathrm{w}$ grupie OS $(5,88)$, następnie w grupie $\mathrm{E}(6,06)$, podczas gdy w grupach A i C wynosiło średnio 6,33 $(\mathrm{P}<0,05)$; wskazuje to na większą produkcję krótkołańcuchowych kwasów tłuszczowych w grupach OS i E. Wydaje się, że mieszanina kwasów organicznych i dodanego symbiotyku może zastępować antybiotykowe stymulatory wzrostu w mieszankach dla kurcząt brojlerów. 